Marquette University

e-Publications@Marquette

Biomedical Sciences Faculty Research and

Publications

Biomedical Sciences, Department of

3-13-2009

\title{
Neuroadaptations in the Cellular and Postsynaptic Group 1 \\ Metabotropic Glutamate Receptor mGluR5 and Homer Proteins Following Extinction of Cocaine Self-administration
}

\author{
M. Behnam Ghasemzadeh \\ Marquette University, behnam.ghasemzadeh@marquette.edu \\ Preethi Vasudevan \\ Marquette University \\ Christopher Mueller \\ Marquette University, christopher.mueller@marquette.edu \\ Chad Seubert \\ Marquette University \\ John R. Mantsch \\ Marquette University, john.mantsch@marquette.edu
}

Follow this and additional works at: https://epublications.marquette.edu/biomedsci_fac

Part of the Neurosciences Commons

\section{Recommended Citation}

Ghasemzadeh, M. Behnam; Vasudevan, Preethi; Mueller, Christopher; Seubert, Chad; and Mantsch, John R., "Neuroadaptations in the Cellular and Postsynaptic Group 1 Metabotropic Glutamate Receptor mGluR5 and Homer Proteins Following Extinction of Cocaine Self-administration" (2009). Biomedical Sciences Faculty Research and Publications. 104.

https://epublications.marquette.edu/biomedsci_fac/104 


\title{
Neuroadaptations in the Cellular and Postsynaptic Group 1 Metabotropic Glutamate Receptor Mglur5 and Homer Proteins Following Extinction of Cocaine Self- Administration
}

\author{
M. Behnam Ghasemzadeh \\ Department of Biomedical Sciences, Integrative Neuroscience \\ Research Center, Marquette University \\ Milwaukee, WI \\ Preethi Vasudevan \\ Department of Biomedical Sciences, Integrative Neuroscience \\ Research Center, Marquette University \\ Milwaukee, WI \\ Christopher Mueller \\ Department of Biomedical Sciences, Integrative Neuroscience \\ Research Center, Marquette University \\ Milwaukee, WI
}


NOT THE PUBLISHED VERSION; this is the author's final, peer-reviewed manuscript. The published version may be accessed by following the link in the citation at the bottom of the page.

\author{
Chad Seubert \\ Department of Biomedical Sciences, Integrative Neuroscience \\ Research Center, Marquette University \\ Milwaukee, WI \\ John R. Mantsch \\ Department of Biomedical Sciences, Integrative Neuroscience \\ Research Center, Marquette University \\ Milwaukee, WI
}

\begin{abstract}
This study examined the role of group1 metabotropic glutamate receptor mGluR5 and associated postsynaptic scaffolding protein Homer1b/c in behavioral plasticity after three withdrawal treatments from cocaine selfadministration. Rats self-administered cocaine or saline for 14 days followed by a withdrawal period during which rats underwent extinction training, remained in their home cages, or were placed in the self-administration chambers in the absence of extinction. Subsequently, the tissue level and distribution of proteins in the synaptosomal fraction associated with the postsynaptic density were examined. Cocaine self-administration followed by home cage exposure reduced the mGluR5 protein in nucleus accumbens (NA) shell and dorsolateral striatum. While extinction training reduced mGluR5 protein in NAshell, NAcore and dorsolateral striatum did not display any change. The scaffolding protein PSD95 increased in NAcore of the extinguished animals. Extinction of drug seeking was associated with a significant decrease in the synaptosomal mGluR5 protein in NAshell and an increase in dorsolateral striatum, while that of NAcore was not modified. Interestingly, both Homer1b/c and PSD95 scaffolding proteins were decreased in the synaptosomal fraction after extinction training in NAshell but not NAcore. Extinguished drug-seeking behavior was also associated with an increase in mGluR5 receptor and actin proteins in dorsolateral striatum. Therefore, extinction of cocaine seeking is associated with neuroadaptations in mGluR5 expression and distribution that are region-specific and consist of extinction-induced reversal of cocaine-induced adaptations as well as emergent extinction-induced alterations. Concurrent plasticity in the scaffolding proteins further suggests that mGluR5 receptor neuroadaptations may have implications for synaptic function.
\end{abstract}

Keywords: Nucleus accumbens, dorsal striatum, receptor trafficking, PSD95, actin, scaffolding protein

Neuroscience Letters, Vol. 452, No. 2 (March 2009): pg. 167-171. DOI. This article is @ Elsevier and permission has been granted for this version to appear in e-Publications@Marquette. Elsevier does not grant permission for this article to be further copied/distributed or hosted elsewhere without the express permission from Elsevier. 
NOT THE PUBLISHED VERSION; this is the author's final, peer-reviewed manuscript. The published version may be accessed by following the link in the citation at the bottom of the page.

\section{Introduction}

A major obstruction in the treatment of addiction has been the propensity to relapse, often mediated by drug-associated cues, even after extended abstinence $[\underline{16}, \underline{18}]$. Accumulating evidence points to enduring neuroadaptations in the glutamatergic signaling in a brain circuit encompassing nucleus accumbens and dorsal striatum as a determining factor in persistent behavioral modifications $[\underline{1}, \underline{7}, \underline{1}, \underline{15}, \underline{24}]$. The neuroplasticity in glutamatergic signaling may not only include receptor expression, but also alterations in receptor trafficking and surface expression.

Cocaine-seeking behavior can be extinguished by allowing animals to emit responses previously associated with cocaine delivery in the absence of drug presentation. Extinction is not simply a reversal of conditioned drug effects that result in self-administration but rather involves attenuation of behaviors that are largely the consequence of the learning of new contextual relationships $[\underline{5}, \underline{29}]$. Accordingly, the extinction of cocaine seeking is likely attributable to the reversal of underlying cocaine-induced adaptations as well as the establishment of novel adaptations that constrain neurobiological processes that contribute to drug use. Recent studies have begun to explore neuroadaptations that contribute to the extinction of cocaine-seeking behavior $[\underline{1}, \underline{7}, \underline{29}, \underline{30}]$. For example, a neural circuit involving the infralimbic cortex and the nucleus accumbens (NA) shell is engaged during extinction in a way that may suppress cocaine seeking [23] $]$.

The group1 metabotropic glutamate receptors (mGluR1 and 5) are $\mathrm{G}_{\mathrm{q} / 11}$-protein-coupled. The trafficking, membrane localization, and function of these receptors are modulated through their interaction with Homer proteins, a family of synaptic scaffolding proteins that selectively bind to these receptors. The Homer proteins are coded by three genes and all member proteins bind to mGluR5 receptors. The Homer proteins form multimer protein complexes and can tether group1 mGluRs, IP3 receptors, and ionotropic glutamate receptors through interaction with Shank proteins [36]. Recent data have implicated mGluR5 receptors and Homer proteins in the behavioral plasticity mediated by drugs of abuse $[13,31, \underline{32}]$. The mGluR5 knockout mice do not develop behavioral sensitization to cocaine or self-

Neuroscience Letters, Vol. 452, No. 2 (March 2009): pg. 167-171. DOI. This article is @ Elsevier and permission has been granted for this version to appear in e-Publications@Marquette. Elsevier does not grant permission for this article to be further copied/distributed or hosted elsewhere without the express permission from Elsevier. 
administer cocaine []ㅡ. The blockade of mGluR5 receptor attenuates cocaine self-administration in primates [25] and rodents [17]. Furthermore, a decrease in Homer1 proteins leads to development of behavioral sensitization to cocaine $[13, \underline{31}]$. Similarly, repeated noncontingent cocaine administration leads to a reduction in Homer proteins in NA $[\underline{3}, \underline{31}]$. These studies suggest that signaling mediated by mGluR 5 receptors and its regulation by Homer proteins are important determinants of behavioral plasticity to drugs of abuse.

This study investigated the role of mGluR5 and Homer1b/c protein expression and subcellular distribution in the extinction of cocaine-seeking behavior in NA core and shell and dorsolateral striatum (dl STR). In order to identify extinction-specific alterations, we studied rats exposed to one of three different withdrawal conditions following self-administration of cocaine or saline.

\section{Experimental Procedures}

All experimental procedures were carried out in accordance with the Guide for the Care and Use of Laboratory Animals as adopted and promulgated by the NIH.

The cocaine self-administration experiments were performed according to procedures previously described [20]. The tissue was processed for biochemical fractionation and western blot analysis as previously described $[\underline{9}, \underline{13}, \underline{35}]$ (Figure 1).

Neuroscience Letters, Vol. 452, No. 2 (March 2009): pg. 167-171. DOI. This article is @ Elsevier and permission has been granted for this version to appear in e-Publications@Marquette. Elsevier does not grant permission for this article to be further copied/distributed or hosted elsewhere without the express permission from Elsevier. 
NOT THE PUBLISHED VERSION; this is the author's final, peer-reviewed manuscript. The published version may be accessed by following the link in the citation at the bottom of the page.

(A)

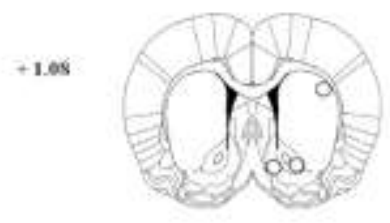

(B)
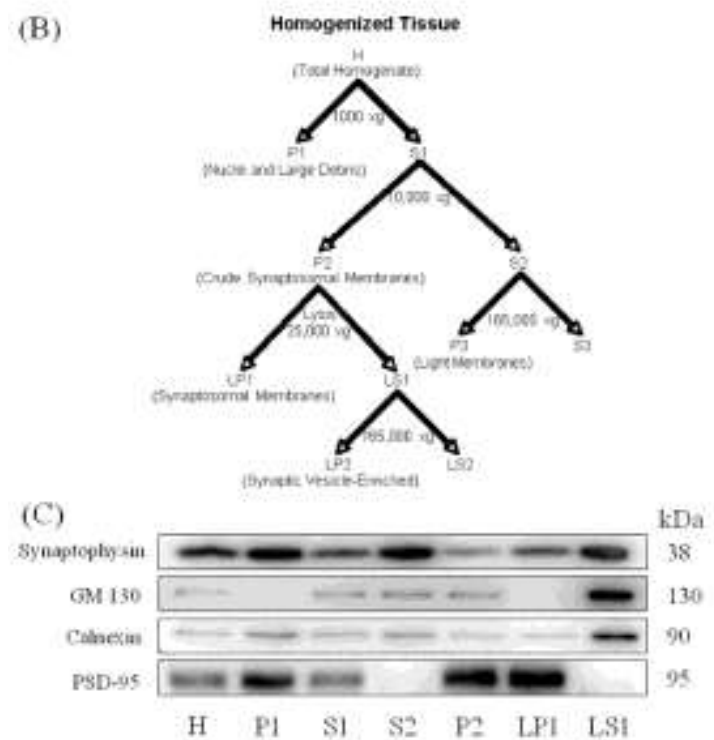

\section{Figure 1 Subcellular fractionation analysis}

Panel A shows the dissection of the nucleus accumbens core and shell and dorsolateral striatum. The numbers on the coronal brain section represent distance from Bregma. Panel B shows a schematic of the subcellular fractionation procedure (adopted from [9]), as described in Materials and Methods. The H and LP1 fractions were used for western blot analysis. Panel $\mathrm{C}$ shows representative immunoblots from nucleus accumbens tissue characterizing the content of each fraction.

\section{Withdrawal conditions}

Cocaine and saline self-administering rats were exposed to one of three conditions during withdrawal. For Extinction, rats selfadministered saline for ten 6-h extinction sessions over a 12-14 day period. For the other two conditions rats did not undergo extinction, but rather remained in their home cages (Home rats) or were introduced into the SA boxes for six hrs each day with the levers retracted and stimulus lights extinguished (Box rats). 
NOT THE PUBLISHED VERSION; this is the author's final, peer-reviewed manuscript. The published version may be accessed by following the link in the citation at the bottom of the page.

\section{Results}

To examine the effects of the withdrawal regimens on the expression and subcellular distribution of glutamate receptors and synaptic scaffolding proteins, Extinction rats and separate groups of Home and Box rats (not tested for cocaine seeking) as well as saline self-administering control rats were killed after 12-14 days of withdrawal and brain regions of interest were collected. The selfadministration of cocaine or saline prior to withdrawal conditions was measured. ANOVA failed to show significant overall differences in saline or cocaine self-administration between rats assigned to the various withdrawal conditions (Day1, Sal/Home $6.1 \pm 1.7, \mathrm{Sal} / \mathrm{Box} 7.9$ \pm 1.4 , Sal/Extinction $10.4 \pm 1.8$, Coc/Home $38.4 \pm 5.4$, Coc/Box 55.4 \pm 4.7, Coc/Extinction $51.9 \pm 8.0 ;$ Day 14, Sal/Home $4.1 \pm 1.4$, Sal/Box $6.2 \pm$ 1.0, Sal/Extinction $2.5 \pm 1.0$, Coc/Home $68.4 \pm 3.3$, Coc/Box $64.1 \pm 7.2$, Coc/Extinction $57.7 \pm 4.4$ ) (Supplementary Figure 1).

Cocaine-seeking behavior was measured in a 6-h session during which responding on the cocaine lever was recorded but cocaine was not available following Home, Box and Extinction treatments. Although responding during cocaine self-administration did not differ among Home, Box, and Extinction treatment groups, a one-way ANOVA showed a significant effect of withdrawal condition on subsequent cocaine seeking (Home, $48.8 \pm 5.2$; Box, $34.4 \pm 5.1$; Extinction, $8.8 \pm$ $1.6 ; F(2,22)=29.916 ; p<0.0001)$. Fisher's PLSD post-hoc test showed that cocaine seeking was significantly lower in Extinction rats compared to both Home and Box rats $(p<0.0001)$ and significantly lower in Box rats compared to Home rats $(p=0.026)$.

The efficacy of the fractionation protocol to isolate various subcellular compartments was illustrated by others $[\underline{9}, \underline{35}, \underline{39}]$ and was reproduced in our laboratory (Figure 1 ). Equal amounts of protein (6 $\mu \mathrm{g})$ from each cellular fraction was analyzed to characterize its content (Figure 1, panel C). Synaptophysin, a presynaptic marker protein [37], was separated from the synaptosomal fraction (P2 vs. S2) and, thus, was present in the synaptosomal membrane fraction at much lower levels (H vs. LP1). Similarly, GM130, a Golgi membrane protein [28], and Calnexin, an endoplasmic reticulum protein [38], were reduced in

Neuroscience Letters, Vol. 452, No. 2 (March 2009): pg. 167-171. DOI. This article is (C) Elsevier and permission has been granted for this version to appear in e-Publications@Marquette. Elsevier does not grant permission for this article to be further copied/distributed or hosted elsewhere without the express permission from Elsevier. 
the synaptosomal membrane fraction while being concentrated in the synaptic vesicle fraction (LP1 vs. LS1). All three intracellular proteins were enriched in the synaptic vesicle-enriched fraction (LS1) and separated from the synaptosomal membrane fraction (LP1). In contrast, PSD-95, a scaffolding protein located at the postsynaptic density [14], was highly enriched in the synaptosomal membrane fraction (H, LS1 vs. LP1). Therefore, the biochemical fractionation enriched the synaptosomal membrane fraction containing the postsynaptic density and separated it from the presynaptic and cytosolic compartments.

Figure 2 shows that the tissue level of the mGluR5 protein in NAshell was significantly decreased in Home and Extinction animals (Home, saline $100 \pm 2.7$, cocaine $87.1 \pm 5.2 ; \mathrm{t}(17)=2.27, \mathrm{p}=0.037$; Extinction, saline $100 \pm 2.4$, cocaine $84.9 \pm 0.041, t(16)=3.18, p=$ 0.006), while there were not any changes in the NAcore. In dl STR, Home animals showed a near significant decrease in the tissue level of mGluR5 (saline $100 \pm 4.1$, cocaine $90.5 \pm 2.4, \mathrm{t}(12)=2.03, \mathrm{p}=$ 0.066), with no changes in the Box and Extinction animals. In the NAcore, there was a significant increase in the redistribution of the mGluR5 into the synaptosomal fraction (LP1 fraction) in Home animals (saline $100 \pm 9.8$, cocaine $131.9 \pm 10.1, \mathrm{t}(14)=-2.24, \mathrm{p}=0.042$ ) but Box and Extinction animals did not show any change. In contrast to NAcore, the NAshell of Extinction animals showed a significant decrease in the synaptosomal redistribution of the mGluR5 (saline 100 \pm 3.0 , cocaine $79.4 \pm 8.1, \mathrm{t}(15)=2.94, \mathrm{p}=0.025)$. In dl STR, there was a significant increase in the synaptosomal redistribution of the mGluR5 receptor protein in Extinction animals (saline $100 \pm 8.5$, cocaine $137.9 \pm 14.3, \mathrm{t}(13)=-2.19, \mathrm{p}=0.047)$. In order to assess the effect of the withdrawal treatments alone on mGluR5 protein, comparisons of saline animals were made across withdrawal conditions. One-way ANOVA did not reveal any differences between the saline groups in either total tissue or synaptosomal mGluR5 levels. Since differences among saline groups were not observed, we were able to compare cocaine-induced changes in total and synaptosomal mGluR5 across withdrawal treatments. At the tissue level, one-way ANOVA revealed significant difference in NAshell $(F(2,26)=5.48, p=$ $0.010)$, and a near significant difference in tissue dl STR $(F(2,20)=3.104, p=0.067)$. Fisher's PLSD Post-hoc comparison of individual treatment groups showed significant differences (NAshell,

Neuroscience Letters, Vol. 452, No. 2 (March 2009): pg. 167-171. DOI. This article is @ Elsevier and permission has been granted for this version to appear in e-Publications@Marquette. Elsevier does not grant permission for this article to be further copied/distributed or hosted elsewhere without the express permission from Elsevier. 
Box vs. Home, $p=0.0136$; Box vs. Extinction, $p=0.006$; dl STR, Home vs. Extinction, $p=0.024)$. In the synaptosomal fraction, there was a significant difference in dI STR $(F(2,19)=6.232, p=0.008)$ across withdrawal treatments in cocaine treated animals. Fisher's PLSD Posthoc comparison of individual treatment groups showed significant differences (dl STR, Home vs. Extinction, $p=0.018$, Box vs. Extinction, $p=0.004)$. There was no difference in NAcore across cocaine treated animals.

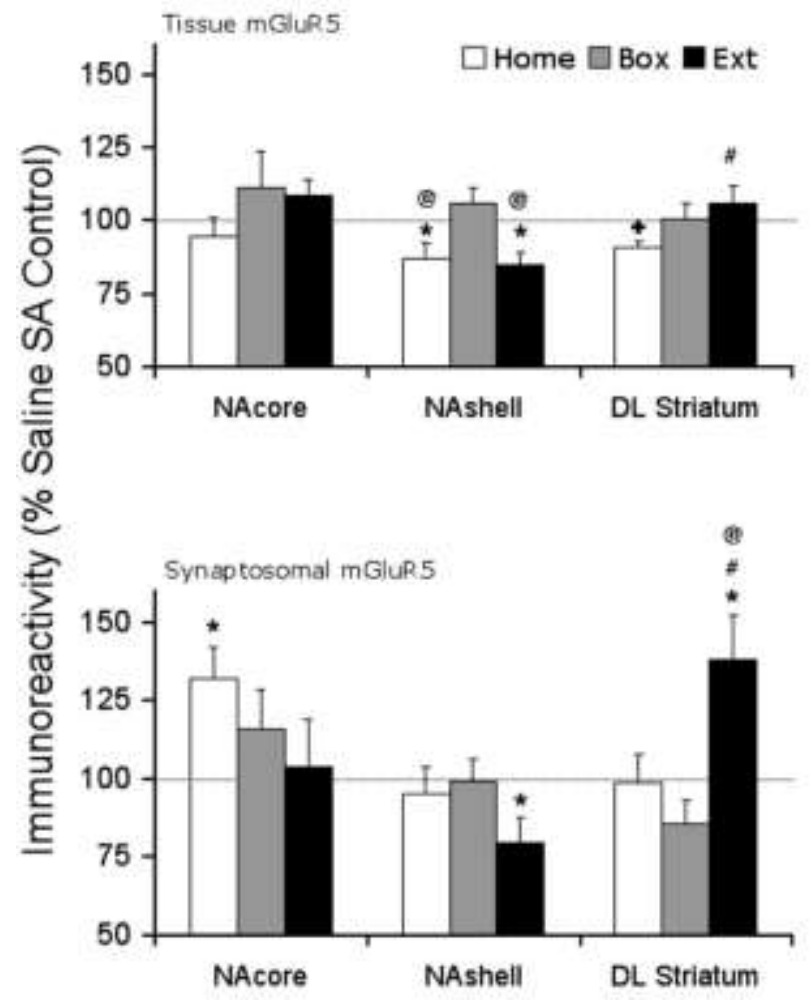

Figure 2 Tissue and synaptosomal membrane fraction levels of mGluR5 receptor protein after cocaine self-administration and Home, Box, and Extinction treatments

At the end of the withdrawal period, all animals were decapitated and brain tissue was dissected for the areas of interest. At the tissue level, mGluR5 protein was reduced significantly in the NAshell of Home and Extinction animals and showed near significant decrease in DL Striatum in Home animals but was not changed under other withdrawal conditions or in other brain regions. In the synaptosomal membrane fraction, mGluR5 receptor protein was increased in NAcore of Home animals and DL striatum of Extinction animals. However, the receptor protein was significantly decreased in the NAshell of extinction animals. $\mathrm{N}=7-11$ rats per treatment group. * $\mathrm{p}$ $<0.05,+p=0.066$ compared to respective saline control. @ $p<0.05$ compared to Box treatment, \# $\mathrm{p}<0.05$ compared to Home treatment. 
Figure 3 shows that the tissue level of Homer $1 \mathrm{~b} / \mathrm{c}$ protein was not modulated in cocaine self-administering rats compared to saline controls in the three regions after any of the withdrawal treatments. In the synaptosomal fraction, there was a significant decrease in the NAshell Homer 1b/c protein in the Extinction animals (saline $100 \pm$ 4.7, cocaine $70.3 \pm 7.6, t(16)=3.31, p=0.004)$. Furthermore, dl STR showed a near significant decrease in the Extinction animals (saline $100 \pm 3.9$, cocaine $87.2 \pm 4.9, \mathrm{t}(10)=2.08, \mathrm{p}=0.065)$. However, the distribution of the Homer $1 \mathrm{~b} / \mathrm{c}$ protein was not changed in the NAcore by any of the withdrawal treatments. One-way ANOVA did not reveal any differences between the saline groups at either tissue level or synaptosomal fraction. Comparing the cocaine treated animals, oneway ANOVA revealed a near significant difference across withdrawal treatments in the tissue NAshell $(F(2,26)=3.224, p=0.056)$. Fisher's PLSD post-hoc comparison of individual groups revealed significant or near significant differences (Box vs. Home, $p=0.056$, Box vs. Extinction, $p=0.027)$. Furthermore, cocaine treated animals showed a significant difference in synaptosomal NAshell across withdrawal treatments $(F(2,25)=9.95, p=0.001)$. Fisher's PLSD post-hoc comparison of individual groups revealed significant differences (synaptosomal, Home vs. Extinction, $\mathrm{p}=0.001$; Box vs. Extinction, $\mathrm{p}=0.001$ ).

Neuroscience Letters, Vol. 452, No. 2 (March 2009): pg. 167-171. DOI. This article is (C Elsevier and permission has been granted for this version to appear in e-Publications@Marquette. Elsevier does not grant permission for this article to be further copied/distributed or hosted elsewhere without the express permission from Elsevier. 


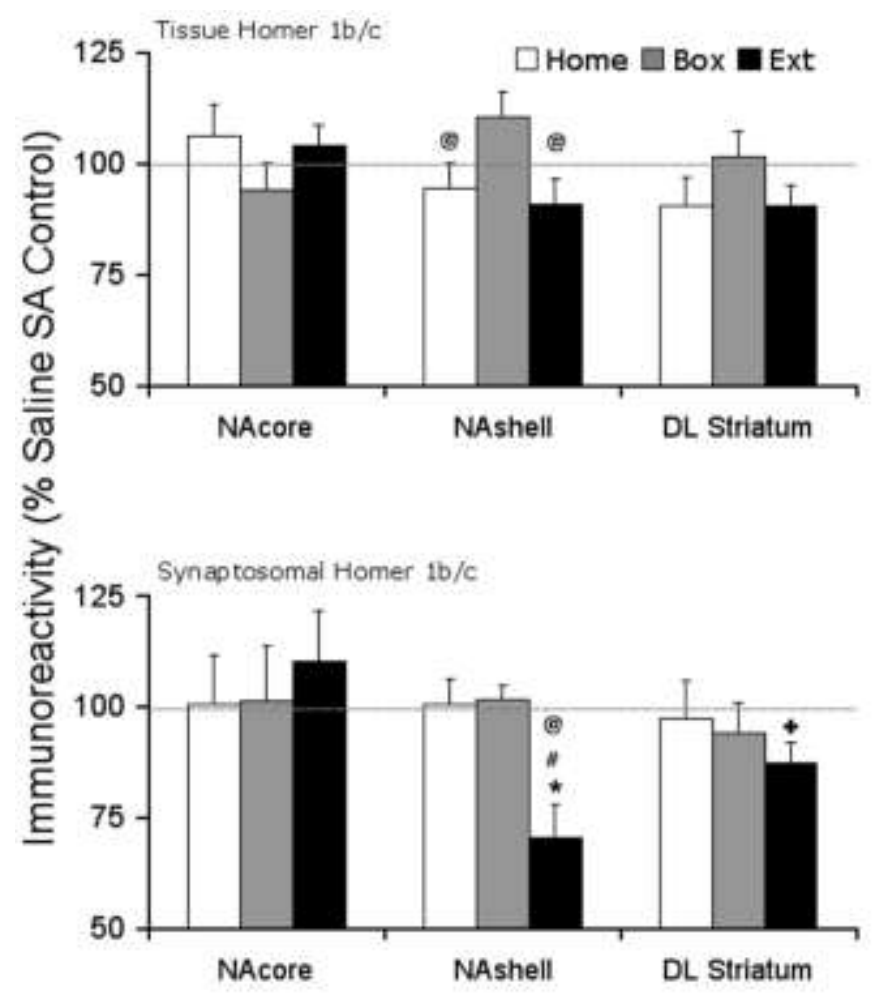

Figure 3 Tissue and synaptosomal membrane fraction levels of Homer $1 \mathrm{~b} / \mathrm{c}$ scaffolding protein after cocaine selfadministration and Home, Box, and Extinction treatments

At the end of the withdrawal period, all animals were decapitated and brain tissue was dissected for the areas of interest. At the tissue level, the protein level was not modified in any withdrawal treatment group in any region examined. In the synaptosomal membrane fraction, Homer $1 \mathrm{~b} / \mathrm{c}$ protein was reduced in NAshell and exhibited a decreasing trend in the dorsolateral Striatum of Extinction animals. There were no changes in the protein level in the NAcore. $\mathrm{N}=7-11$ rats per treatment group. $* p<0.05,+p=0.065$ compared to respective saline control. @ $p<0.05$ compared to Box treatment, \# $\mathrm{p}<0.05$ compared to Home treatment.

The Extinction animals indicated a significant increase in the tissue level of the postsynaptic scaffolding protein PSD-95 in the NAcore (saline $100 \pm 2.4$, cocaine $111.9 \pm 4.6 ; \mathrm{t}(17)=-2.20, \mathrm{p}=$ 0.042 ) while there were no changes in the NAshell or dl STR tissue. In the synaptosomal membrane fraction, there was a strong decreasing trend in the NAshell of Extinction animals (saline $100 \pm 5.1$, cocaine $85.4 \pm 5.7 ; \mathrm{t}(18)=1.90, \mathrm{p}=0.074)$. However, NAcore and dl STR did not exhibit any changes in the distribution of PSD-95 protein under different withdrawal regimen. One-way ANOVA did not reveal any 
differences between the saline or cocaine groups at either tissue level or synaptosomal fraction (Supplementary Figure 2).

Comparing cocaine and saline self-administrating rats, the tissue level of actin protein was not changed in any withdrawal group in any region examined. In the synaptosomal membrane fraction, the Extinction animals indicated a significant increase in the redistribution of the actin protein in the dl STR (saline $100 \pm 6.4$, cocaine $130.4 \pm$ $12.3, \mathrm{t}(14)=-2.20, \mathrm{p}=0.045)$, while the nucleus accumbens was not affected. One-way ANOVA did not reveal any differences between the saline or cocaine groups at either tissue level or synaptosomal fraction (Supplementary Figure 3 ). Supplementary figures 4 and $\underline{5}$ show representative protein bands for proteins examined in NA and dl STR, respectively.

\section{Discussion}

The main observation in this study was that the synaptosomal level of mGluR5 protein was decreased in NAshell of Extinction animals, suggesting a decrease in the mGluR5 receptor signaling. A concurrent reduction in Homer1b/c and PSD95 postsynaptic scaffolding proteins in synaptosomal NAshell further supports the extinctionmediated decrease in mGluR5 receptor function. This decrease was selective for the Extinction animals since the Home and Box animals did not show any changes in the proteins measured. In fact, at the synaptosomal level, cocaine Extinction animals had a significantly reduced Homer1b/c protein level compared to Home and Box treated animals. These observations suggest that a reduction in mGluR5 receptor function in NAshell is associated with extinction of drugseeking behavior. This is in agreement with the observation that a decreased activity at the mGluR5 receptors reduced cocaine selfadministration $[\underline{6}, \underline{17}, \underline{25}]$. Furthermore, the blockade of mGluR5 receptor reduces self-administration of other drugs of abuse such as methamphetamine, alcohol, and nicotine [For example see $\underline{3}, \underline{12}, \underline{22}, \underline{33}]$.

Observed changes in the mGluR5 receptor protein levels mostly in the extinguished rats suggest that alterations in receptor expression, trafficking and/or distribution may regulate cocaineseeking behavior. To explore potential mechanisms for receptor

Neuroscience Letters, Vol. 452, No. 2 (March 2009): pg. 167-171. DOI. This article is ( Elsevier and permission has been granted for this version to appear in e-Publications@Marquette. Elsevier does not grant permission for this article to be further copied/distributed or hosted elsewhere without the express permission from Elsevier. 
redistribution, we examined tissue and synaptosomal expression of the Homer1b/c scaffolding protein. Homer proteins regulate group1 metabotropic glutamate receptor (mGluR1 and mGluR5) trafficking, membrane expression and intracellular signaling $[\underline{2}, \underline{36}, \underline{39}]$. Therefore, a coordinated decrease in both mGluR5 and Homer1b/c proteins in the synaptosomal fraction of NAshell, but not core, suggest that a decrease in mGluR5 receptor trafficking to the postsynaptic density may be associated with the extinction of drug-seeking behavior. In contrast, the mGluR5 protein increases in synaptosomal fraction of NAcore in Home animals suggest a distinct role for mGluR5 receptors in NAcore versus NAshell. Further evidence for a decrease in NAshell signaling is suggested by a selective decrease in PSD95 scaffolding proteins in the NAshell of extinguished animals. PSD95 protein is found at the postsynaptic density of the excitatory synapses [14], physically interacts with both AMPA and NMDA receptors $[\underline{19}, \underline{26}]$ and is tethered to mGluR5 receptors through interaction with Shank proteins $[10,26, \underline{36}]$. Thus, alterations in the Homer1b/c and PSD95 proteins may have contributed to the reduction in the synaptosomal mGluR5 in extinguished animals after cocaine self-administration. These data are in general agreement with the observed reduction in Homer proteins in NA after behavioral sensitization to cocaine $[\underline{3}, \underline{31}]$. Therefore, our findings suggest that the extinction of cocaine self-administration is associated with a postsynaptic reorganization in both the NA core and shell that likely contributes to extinction-induced reductions in cocaineseeking behavior.

Recent findings have suggested that the dorsal striatum is also critical for cocaine-seeking behavior, and may in fact mediate drug seeking in the absence of extinction [11]. Therefore, we explored the neuroadaptations in dI STR induced by cocaine self-administration and extinction that may influence cocaine seeking. Cocaine selfadministration reduced the tissue level of mGluR5 receptor protein in the dl STR, an effect that was reversed by extinction, while extinction training produced a significant increase in synaptosomal mGluR5 protein. Similarly, extinction training produced a significant increase in the synaptosomal actin, a postsynaptic scaffolding protein involved in maintenance and regulation of synaptic structure and dendritic spine function [35]. While there was no change in the tissue levels of Homer1b/c protein, extinction training reduced the protein levels in $\mathrm{dl}$ STR.

Neuroscience Letters, Vol. 452, No. 2 (March 2009): pg. 167-171. DOI. This article is @ Elsevier and permission has been granted for this version to appear in e-Publications@Marquette. Elsevier does not grant permission for this article to be further copied/distributed or hosted elsewhere without the express permission from Elsevier. 
NOT THE PUBLISHED VERSION; this is the author's final, peer-reviewed manuscript. The published version may be accessed by following the link in the citation at the bottom of the page.

In summary, the present study demonstrates that the extinction of cocaine self-administration produces changes in the mGluR5 protein expression and subcellular distribution that are region-specific and appear to consist of both extinction-induced reversal of adaptations brought on by abstinence as well as new emergent extinction-induced alterations that appear to include a modulation of the receptor protein at the postsynaptic density and alterations in scaffolding proteins. Importantly, these alterations further suggest that extended cocaine exposure is associated with neuroplasticity in excitatory signaling in the striatum in a way that determines cocaine-seeking behavior. 


\section{Supplementary Material}

\section{SFig1}

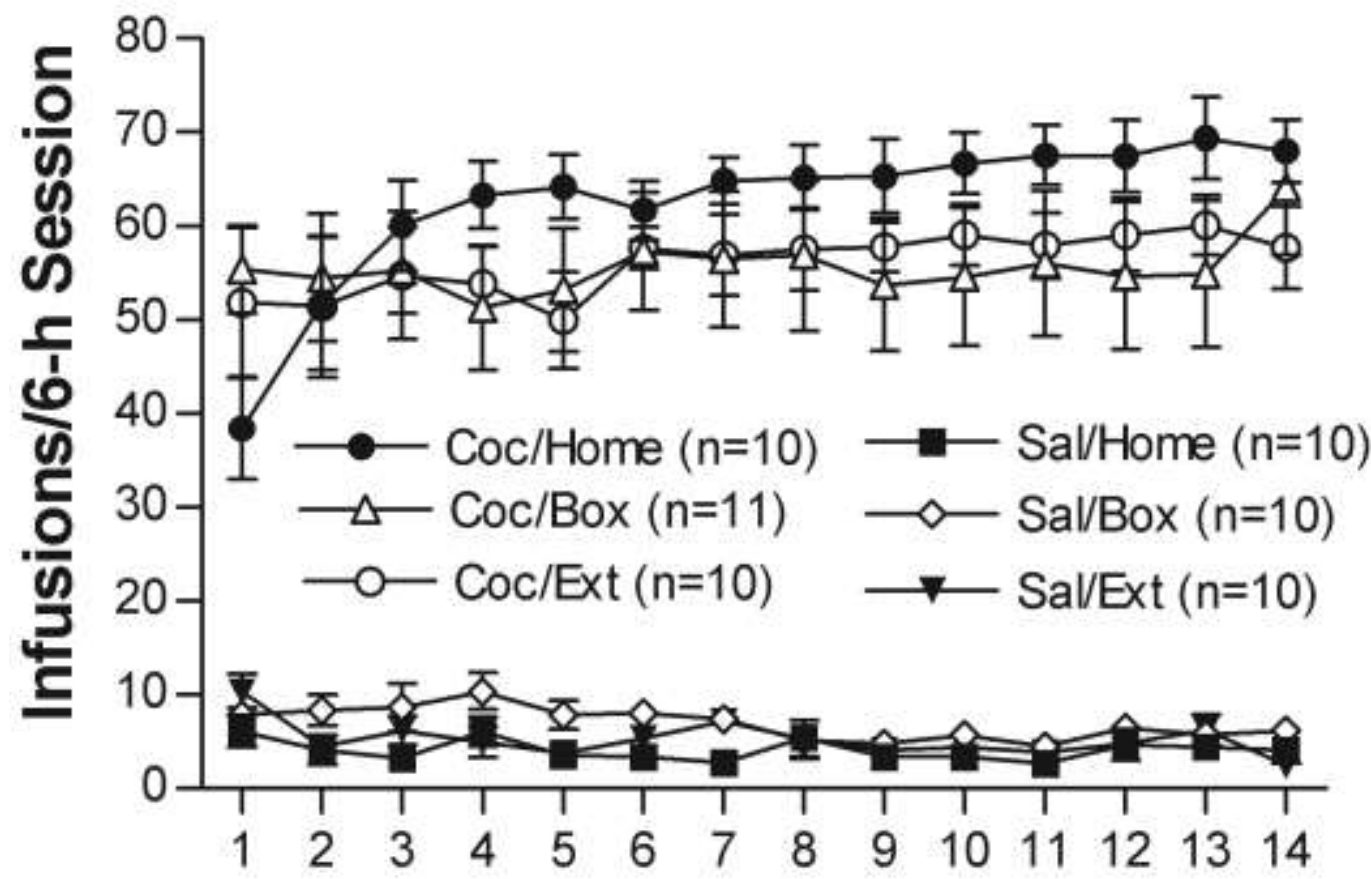

SA Session 
NOT THE PUBLISHED VERSION; this is the author's final, peer-reviewed manuscript. The published version may be accessed by following the link in the citation at the bottom of the page.

\section{SFig2}

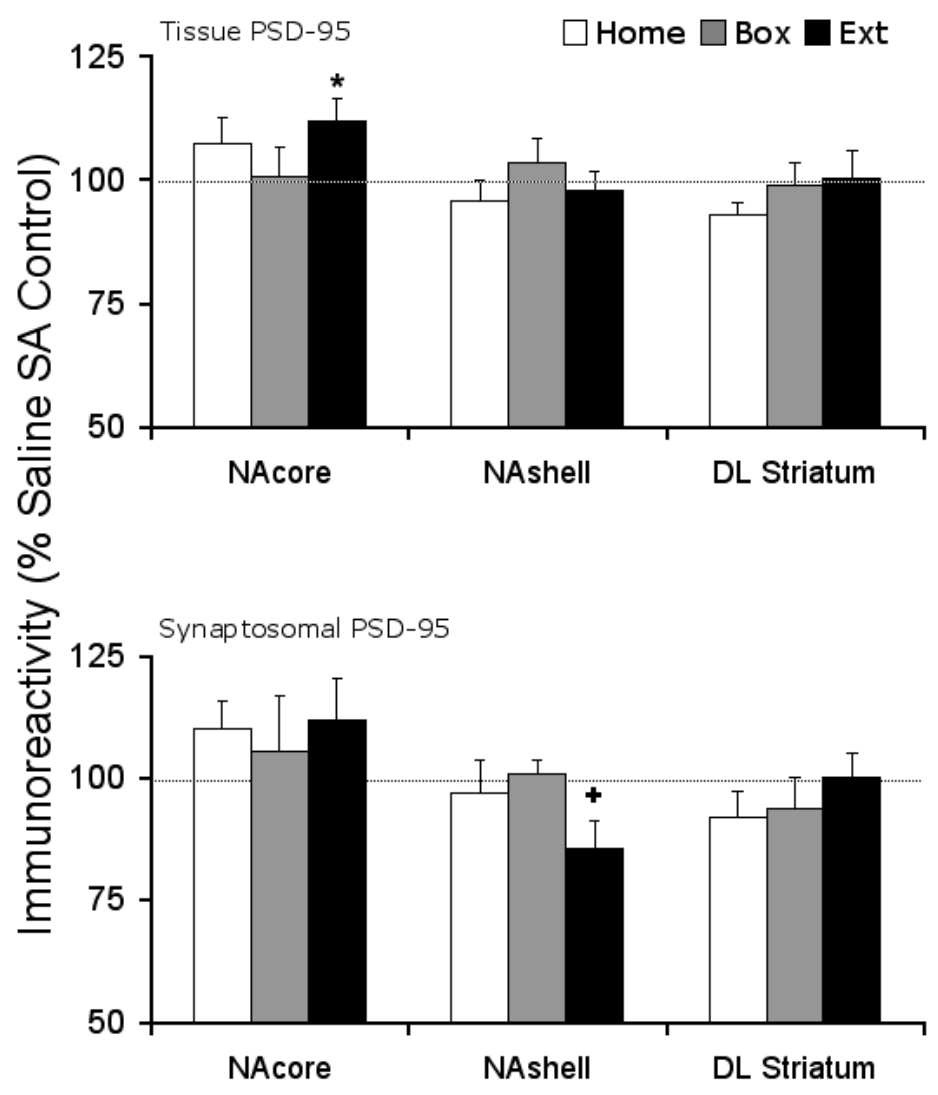

Neuroscience Letters, Vol. 452, No. 2 (March 2009): pg. 167-171. DOI. This article is (C Elsevier and permission has been granted for this version to appear in e-Publications@Marquette. Elsevier does not grant permission for this article to be further copied/distributed or hosted elsewhere without the express permission from Elsevier. 
NOT THE PUBLISHED VERSION; this is the author's final, peer-reviewed manuscript. The published version may be accessed by following the link in the citation at the bottom of the page.

\section{SFig3}

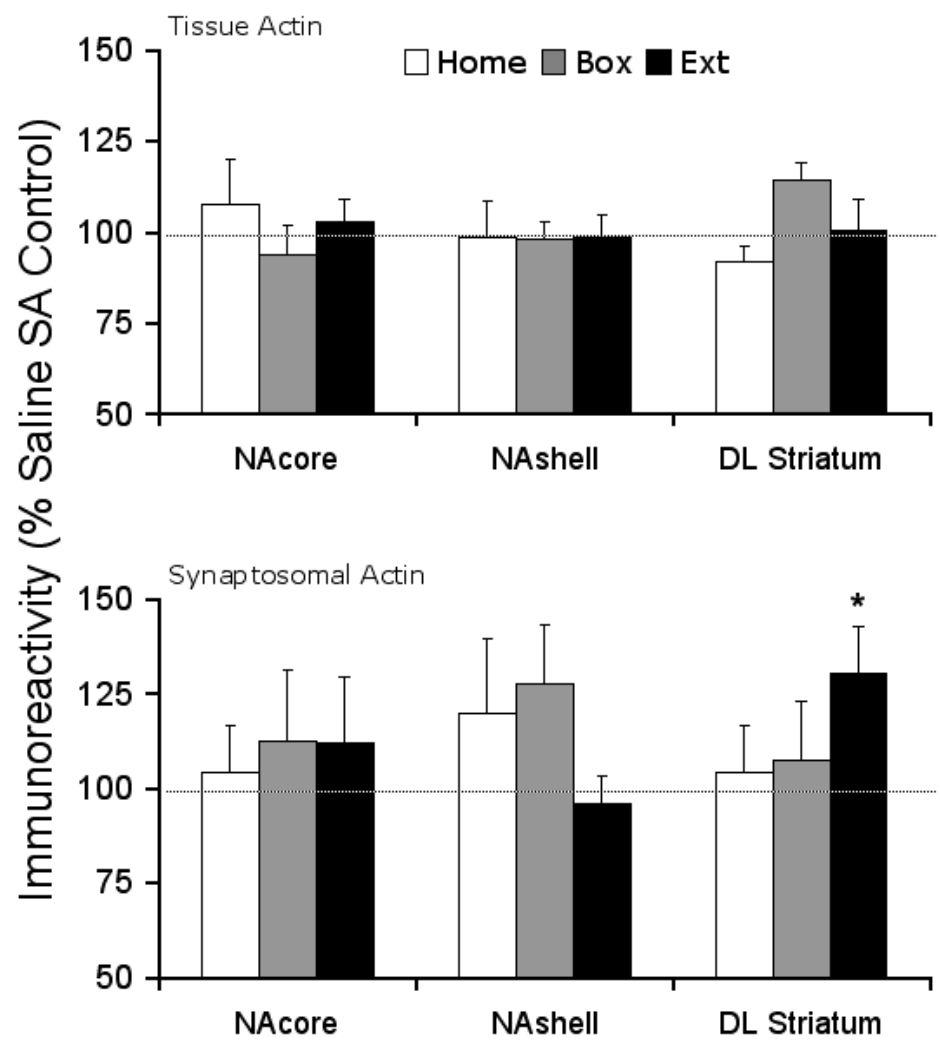

Neuroscience Letters, Vol. 452, No. 2 (March 2009): pg. 167-171. DOI. This article is @ Elsevier and permission has been granted for this version to appear in e-Publications@Marquette. Elsevier does not grant permission for this article to be further copied/distributed or hosted elsewhere without the express permission from Elsevier. 
NOT THE PUBLISHED VERSION; this is the author's final, peer-reviewed manuscript. The published version may be accessed by following the link in the citation at the bottom of the page.

\title{
SFig4
}

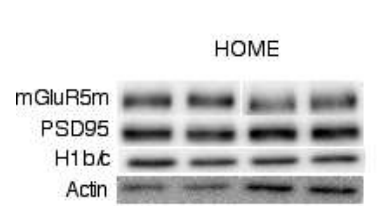

Actin $-\cdots$
NA CORE - H

BOX

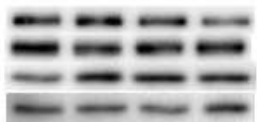

NA CORE - LP1
HOME

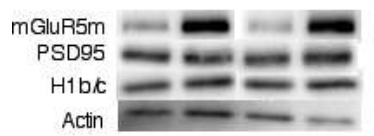

$\mathrm{BOX}$

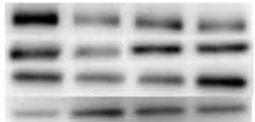

NA SHELL - H

BOX

HOME

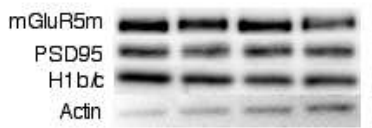

NA SHELL - LP1

HOME

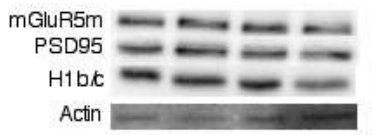

Saline Cocaine Saline Cocaine
$\mathrm{BOX}$

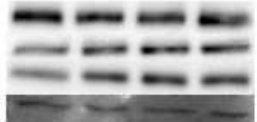

Saline Cocaine Saline Cocaine
EXTINCTION

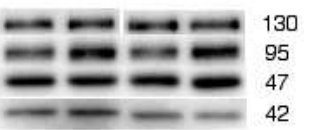

EXTINCTION

$=-130$

$=-m=55$

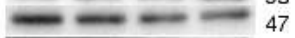

$---42$

\section{SFig5}

\author{
DL STR - H
}

HOME BOX

EXTINCTION

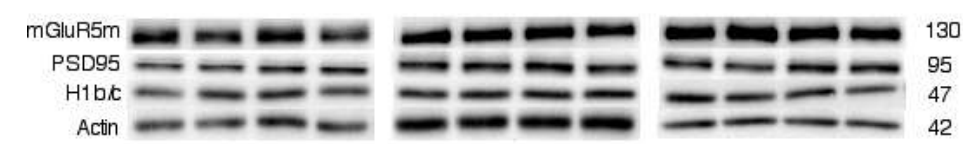

DLSTR - LP1

HOME BOX

EXTINCTION

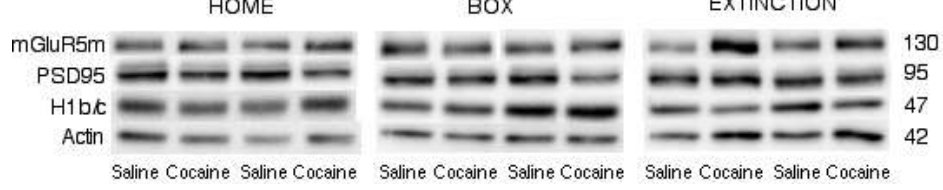

Neuroscience Letters, Vol. 452, No. 2 (March 2009): pg. 167-171. DOI. This article is C) Elsevier and permission has been granted for this version to appear in e-Publications@Marquette. Elsevier does not grant permission for this article to be further copied/distributed or hosted elsewhere without the express permission from Elsevier. 
NOT THE PUBLISHED VERSION; this is the author's final, peer-reviewed manuscript. The published version may be accessed by following the link in the citation at the bottom of the page.

Acknowledgements: This work was supported by United States Public Service Grant numbers DA14328 (MBG) and DA15758 (JRM).

Footnotes: The complete description of materials and methods is available online as supplemental material.

\section{References}

1. Anderson SM, Famous KR, Sadri-Vakili G, Kumaresan V, Schmidt HD, Bass $\mathrm{CE}$, Terwilliger EF, Cha JJ, Pierce RC. CaMKII: a biochemical bridge linking accumbens dopamine and glutamate systems in cocaine seeking. Nature Neurosci. 2008;11:344-353.

2. Ango F, Robbe D, Tu JC, Xiao B, Worley PF, Pin JP, Bockaert J, Fagni L. Homer-dependent cell surface expression of metabotropic glutamate receptor type 5 in neurons. Mol. Cell. Neurosci. 2002;20:323-329.

3. Ary AW, Szumlinski KK. Regional differences in the effects of withdrawal from repeated cocaine upon Homer and glutamate receptor expression: A two-species comparison. Brain Res. 2007;1184:295305.

4. Bäckström P, Bachteler D, Koch S, Hyytiä P, Spanagel R. mGluR5 antagonist MPEP reduces ethanol-seeking and relapse behavior. Neuropsychopharmacology. 2004;29:921-928.

5. Bouton ME. Context, ambiguity, and unlearning: sources of relapse after behavioral extinction. Biol. Psychiatry. 2002;52:976-986.

6. Chiamulera C, Epping-Jordan MP, Zocchi A, Marcon C, Cottiny C, Tacconi S, Corsi $\mathrm{M}$, Orzi $\mathrm{F}$, Conquet $\mathrm{F}$. Reinforcing and locomotor stimulant effects of cocaine are absent in mGluR5 null mutant mice. Nature Neurosci. $2001 ; 4: 873-874$.

7. Conrad KI, Tseng KY, Uejima JL, Reimers JM, Heng L, Shaham Y, Marinelli M, Wolf M. Formation of accumbens GluR2-lacking AMPA receptors mediates incubation of cocaine craving. Nature. 2008;454:118-124.

8. Cornish JL, Kalivas PW. glutamate transmission in the nucleus accumbens mediates relapse in cocaine addiction. J. Neurosci. 2000;20 89RC (1$5)$.

9. Dunah AW, Standaert DG. Dopamine D1 receptor-dependent trafficking of striatal NMDA glutamate receptors to the postsynaptic membrane. J. Neurosci. 2001;21:5546-5558.

10. Ehrlich I, Malinow R. Postsynaptic density 95 controls AMPA receptor incorporation during long-term potentiation and experience-driven synaptic plasticity. J. Neurosci. 2004;24:916-927.

11. Fuchs RA, Branham RK, See RE. Different neural substrates mediate cocaine seeking after abstinence versus extinction training: a critical

Neuroscience Letters, Vol. 452, No. 2 (March 2009): pg. 167-171. DOI. This article is @ Elsevier and permission has been granted for this version to appear in e-Publications@Marquette. Elsevier does not grant permission for this article to be further copied/distributed or hosted elsewhere without the express permission from Elsevier 
role for the dorsolateral caudate-putamen. J. Neurosci. 2006;26:35843588.

12. Gass JT, Osborne MP, Watson NL, Brown JL, Olive MF. mGluR5 Antagonism Attenuates Methamphetamine Reinforcement and Prevents Reinstatement of Methamphetamine-Seeking Behavior in Rats. Neuropsychopharmacology. 2008 Sep 17;

13. Ghasemzadeh MB, Permenter LK, Lake R, Worley PF, Kalivas PW. Homer1 Proteins and AMPA receptors modulate cocaine-induced behavioral plasticity. Eur. J. Neurosci. 2003;18:1645-1651.

14. Hunt CA, Schenker LJ, Kennedy MB. PSD95 is associated with the postsynaptic density and not with the presynaptic membrane at forebrain synapses. J. Neurosci. 1996;16:1380-1388.

15. Kalivas PW, McFarland K. Brain circuitry and the reinstatement of cocaineseeking behavior. Psychopharmacology. 2003;168:44-56.

16. Kalivas PW, Volkow ND. The neural basis of addiction: a pathology of motivation and choice. Am. J. Psychiatry. 2005;162:1403-1413.

17. Kenny PJ, Boutrel B, Gasparini F, Koob GF, Markou A. Metabotropic glutamate 5 receptor blockade may attenuate cocaine selfadministration by decreasing brain reward function in rats. Psychopharmacology. 2005;179:247-254.

18. Koob G, Kreek MJ, Stress J. dysregulation of drug reward pathways, and the transition to drug dependence. Am. J. Psychiatry. 2007;164:11491159.

19. Kornau HC, Schenker LT, Kennedy MB, Seeburg PH. Domain interaction between NMDA receptor subunits and the postsynaptic density protein PSD-95. Science. 1995;269:1737-1740.

20. Mantsch JR, Baker DA, Serge JP, Hoks MA, Francis DM, Katz ES. Surgical adrenalectomy and diurnal corticosterone replacement slows escalation and prevents the augmentation of cocaine-induced reinstatement in rats self-administering cocaine under long-access conditions. Neuropsychopharmacology. 2008;33:814-826.

22. Paterson NE, Semenova S, Gasparini F, Markou A. The mGluR5 antagonist MPEP decreased nicotine self-administration in rats and mice. Psychopharmacology (Berl) 2003;167:257-264.

23. Peters J, LaLumiere RT, Kalivas PW. Infralimbic cortex is responsible for inhibiting cocaine seeking in extinguished rats. J. Neurosci. 2008;28:6046-6053.

24. Ping A, Xi J, Prasad BM, Wang MH, Kruzich PJ. Contributions of nucleus accumbens core and shell GluR1 containing AMPA receptors in AMPAand cocaine-primed reinstatement of cocaine-seeking behavior. Brain Res. $2008 ; 1215: 173-182$.

25. Platt DM, Rowlett JK, Spealman RD. Attenuation of cocaine selfadministration in squirrel monkeys following repeated administration of

Neuroscience Letters, Vol. 452, No. 2 (March 2009): pg. 167-171. DOI. This article is @ Elsevier and permission has been granted for this version to appear in e-Publications@Marquette. Elsevier does not grant permission for this article to be further copied/distributed or hosted elsewhere without the express permission from Elsevier. 
NOT THE PUBLISHED VERSION; this is the author's final, peer-reviewed manuscript. The published version may be accessed by following the link in the citation at the bottom of the page.

the mGluR5 antagonist MPEP: comparison with dizocilpine.

Psychopharmacology. 2008:167-176.

26. Schnell E, Sizemore M, Karimzadegan S, Chen L, Bredt DS, Nicoll RA. Direct interactions between PSD95 and stargazing control synaptic AMPA receptor number. Proc. Natl. Acad. Sci. USA. 2002;99:1390213907.

28. Seemann J, Jokitalo EJ, Warren G. The role of the tethering proteins p115 and GM130 in transport through the Golgi apparatus in vivo. Mol. Biol. Cell. 2000;11:635-645.

29. Self DW, Choi K, Simmons D, Walker JR, Smagula CS. Extinction training regulates neuroadaptive responses to withdrawal from chronic cocaine self-administration. Learning \& memory. 2004;11:648-657.

30. Sutton MA, Schmidt EF, Choi K, Schad CA, Whisler K, Simmons D, Karanian DA, Monteggia LM, Neve RL, Self DW. Extinction-induced upregulation in AMPA receptors reduces cocaine-seeking behaviour. Nature. 2003;421:70-75.

31. Swanson CJ, Baker DA, Carson D, Worley PF, Kalivas PW. Repeated cocaine administration attenuates group I metabotropic glutamate receptor-mediated glutamate release and behavioral activation: a potential role for homer. J. Neurosci. 2001;21:9043-9052.

32. Szumlinski KK, Dehoff MH, Kang SH, Frys KA, Lominac KD, Klugmann M, Rohrer J, Griffin W, III, Toda S, Champtiaux NP, Berry T, Tu JC, Shealy SE, During MJ, Middaugh LD, Worley PF, Kalivas PW. Homer proteins regulate sensitivity to cocaine. Neuron. 2004;43:401-413.

33. Tessari M, Pilla M, Andreoli M, Hutcheson DM, Heidbreder CA. Antagonism at metabotropic glutamate 5 receptors inhibits nicotine- and cocainetaking behaviours and prevents nicotine-triggered relapse to nicotineseeking. Eur. J. Pharmacol. 2004;499:121-133.

35. Toda S, Shen HW, Peters J, Cagle S, Kalivas PW. Cocaine increases actin cycling: effects in the reinstatement model of drug seeking. $J$. Neurosci. 2006;26:1579-1587.

36. Tu JC, Xiao B, Naisbitt S, Yuan JP, Petralia RS, Brakeman P, Doan A, Aakalu VK, Lanahan AA, Sheng M, Worley PF. Coupling of mGluR/Homer and PSD-95 complexes by the shank family of postsynaptic density proteins. Neuron. 1999;23:583-592.

37. Wiedenmann B, Franke WW. Identification and localization of synaptophysin, an integral membrane glycoprotein of $\mathrm{Mr} 38,000$ characteristic of presynaptic vesicles. Cell. 1985;41:1017-1028.

38. Williams DB. Beyond lectins: the calnexin/calreticulin chaperone system of the endoplasmic reticulum. J. Cell. Sci. 2006;119:615-623.

39. Xiao B, Tu JC, Petralia RS, Yuan JP, Doan A, Breder CD, Ruggiero A, Lanahan AA, Wenthold RJ, Worley PF. Homer regulates the association of group 1 metabotropic glutamate receptors with multivalent

Neuroscience Letters, Vol. 452, No. 2 (March 2009): pg. 167-171. DOI. This article is @ Elsevier and permission has been granted for this version to appear in e-Publications@Marquette. Elsevier does not grant permission for this article to be further copied/distributed or hosted elsewhere without the express permission from Elsevier. 
NOT THE PUBLISHED VERSION; this is the author's final, peer-reviewed manuscript. The published version may be accessed by following the link in the citation at the bottom of the page.

complexes of homer-related, synaptic proteins. Neuron. 1998;21:707716.

\section{About the Authors}

Corresponding Author: M. Behnam Ghasemzadeh, Marquette University, Department of Biomedical University, $561 \mathrm{~N} .15^{\text {th }}$ Street, SC 446, Milwaukee, WI 53233, Email: behnam.ghasemzadeh@marquette.edu 